\title{
Multidecadal Changes in the Relationship of Storm Frequency over Euro-Mediterranean Region and ENSO During Boreal Winter
}

\author{
Shahzad Kamil ${ }^{1} \cdot$ Mansour Almazroui $^{1} \cdot$ Fred Kucharski $^{1,2} \cdot$ In-Sik Kang $^{1,3}$
}

Received: 7 February 2017 / Accepted: 1 August 2017/Published online: 7 August 2017

(c) The Author(s) 2017. This article is an open access publication

\begin{abstract}
Background The El Niño-Southern Oscillation (ENSO) influence over Euro-Mediterranean boreal winter season (December to February) precipitation anomalies has changed along the twentieth century.

Purpose The precipitation anomalies are closely associated with storm track frequency. The changing relationship between the interannual variability of storm track frequency and ENSO is investigated at interannual and multidecadal timescales.

Methods The Melbourne University cyclone tracking scheme (MS) is applied to reanalyse 200-hPa geopotential height (Z200) datasets to track the winter storms over the Euro-Mediterranean region for the period 1950-2016.

Results The maximum of climatological storm track frequency is found to prevail in the study domain with large interannual variability. The multidecadal changes show a phase shift in the relationship between storm track frequency and ENSO from the 1950s to the recent decades. The storm track frequency is negatively correlated $(-0.24)$ to ENSO for the early period (1950-1979), whereas it is positively correlated with a maximum correlation value of 0.44 for the recent period (1987-2016). The correlation departure $(0.68)$ between the two periods shows a
\end{abstract}

Shahzad Kamil

kamilcheema@gmail.com

1 Department of Meteorology, Center of Excellence for Climate Change Research, King Abdulaziz University, P. O. Box 80208, Jeddah 21589, Saudi Arabia

2 International Centre for Theoretical Physics, Trieste, Italy

3 School of Earth and Environmental Sciences, Seoul National University, Seoul, South Korea significant change in the multidecadal relationship between storm track frequency and ENSO.

Conclusion The ENSO-associated significant changes are noted in the upper and lower tropospheric height anomalies over the North Atlantic and Euro-Mediterranean sector in the recent period with respect to the earlier period, which may largely influencing the storm activity (Frequency/Intensity) and precipitation anomalies over the Euro-Mediterranean region. The findings of this study can have important implications in Euro-Mediterranean seasonal predictability.

Keywords Storm Tracks · ENSO - Euro-Mediterranean · Precipitation $\cdot$ MS Scheme $\cdot$ North Atlantic

\section{Introduction}

The El Niño-Southern Oscillation (ENSO) is globally the dominant mode of climatic variability at interannual timescales. It has variable effects over the Pacific, North Atlantic, Euro-Mediterranean and tropical regions (Diaz et al. 2001; McPhaden et al. 2006; Bronnimann 2007; Lopez-Parages and Rodriguez-Fonseca 2012). The interannual variability induced by the atmospheric circulation over the North Atlantic and Euro-Mediterranean region is large, making it hard to detect a noticeable ENSO signal. It has long been a matter of debate whether and how ENSO warm and cold extreme episodes influence Euro-Mediterranean rainfall. The ENSO relationship with global and regional precipitation anomalies has been discussed in the literature (Ropelewski and Halpert 1987; Nakamura et al. 2004; Kang et al. 2015; Abid et al. 2016 and others). The explanation for this teleconnection is related to changes in the tropical walker circulation that dramatically influence the tropical belt during ENSO years. Therefore, the 
changes in the zonal circulation in the tropics impact midlatitude weather by changing the intensity and position of the subtropical jet stream and the meridional advection of moisture and heat. In the central and eastern Pacific Ocean, the anomalous warming during ENSO events causes an equatorward shift of subtropical jet stream from its mean position, and hence changing the position of low and high pressure systems along Rossby waves connected with the jet stream (Straus and Shukla 1997; Wang 2002; Bronnimann 2007; Niranjan Kummar et al. 2016).

Nonstationary features in the climatic impacts of ENSO over Euro-Mediterranean region were found in earlier studies (Greatbach et al. 2004; Lopez-Parages and Rodriguez-Fonseca 2012) showing different influences of ENSO before and after the 1980s. The climatological precipitation anomalies in Euro-Mediterranean are very much associated with decadal variations in frequency and intensity of storm tracks (Chang and Fu 2002; Shaw et al. 2016). The ENSO impact over Euro-Mediterranean climate is nonstationary on multidecadal scales and it is contributing to a large interannual variability of storm frequency and precipitation (Bronnimann 2007; Lopez-Parages and Rodriguez-Fonseca 2012; Van-Oldenborgh and Burgers 2005; Herceg Bulic and Kucharski 2012; Ehsan et al. 2013). The storm tracks play the role of an atmospheric bridge through which the effects of tropical Pacific Sea surface temperature (SST) anomalies associated with ENSO are transferred into the mid-latitudes in the form of precipitation and heat (Alexander 1992; Lau and Nath 2001; Abid et al. 2015). The extratropical storm tracks advect the moisture from the oceans to the land and in the regions such as Europe and North America and account for over $70 \%$ of the total precipitation during the winter season (Hawcroft et al. 2012; Ehsan et al. 2017).

The strength of teleconnection appears to change over the second half of the twentieth century. This change is revealed by running correlations technique where the correlation coefficient is calculated in the corresponding intervals and plotted as a function of the central year in this interval. The running correlations of the teleconnections to rainfall over Euro-Mediterranean and some other regions reveal large fluctuations (Knippertz et al. 2003; Mariotti et al. 2002; Van-Oldenborgh and Burgers 2005; LopezParages and Rodriguez-Fonseca 2012; Kang et al. 2015). Similarly, to find these fluctuations in the internal mode of the atmosphere with respect to ENSO, similar running correlations to storm frequency over Euro-Mediterranean region are considered.

Previously objective storm tracking methods have been used at multiple level meteorological fields to identify the regions where extratropical storms are statistically most common in the northern hemisphere mid-latitudes, that is, the North Pacific, North Atlantic and the Euro-Mediterranean region (Hoskins and Hodges 2002; Shaw et al. 2016). It was suggested that storm tracks at lower tropospheric levels live in more limited longitudinal sectors and many of the storms are possibly generated by upper tropospheric disturbances in a curved band of activity. In the past studies, the criterion of geopotential height based cyclone detection and tracking (Trigo et al. 1999; Almazroui et al. 2016) was performed to locate cyclogenesis and cyclolysis regions, as well as cyclone characteristics in Mediterranean region.

The objective of this paper is to investigate the multidecadal relationship between the storm tracks frequency in the Euro-Mediterranean region and ENSO. In Sect. 2, the data and methodology are described, whereas the results and discussion are described in Sect. 3. Section 4 contains the summary and conclusion part.

\section{Data and Methodology}

For identification and tracking of storms, the NCEP/NCAR Z200 6-hourly reanalysis dataset is used in Melbourne University cyclone tracking scheme (MS). Further, the monthly mean of geopotential height dataset is used for seasonal analysis. The precipitation dataset (1979-2016) was obtained from the Global Precipitation Climatology Project (GPCP) to construct the ENSO composite in EuroMediterranean region. The spatial grid resolution of the GPCP data is $2.5^{\circ} \times 2.5^{\circ}$ in longitude and latitude (Adler et al. 2003). The monthly mean of Global SST data (COBE-SST) was obtained from National Oceanic Atmospheric Administration (Ishii et al. 2005), which covers the period from 1891 to 2016. The horizontal grid resolution of global SST dataset is $1^{\circ} \times 1^{\circ}$ in longitude and latitude. This SST dataset is used for the purpose of correlations and ENSO composite analysis.

The Melbourne University storm tracking scheme (MS) is a state-of-the art method for analyzing low and high pressure centers on a sphere and calculating the trajectories and characteristics (Murray and Simmonds 1991a, b). This scheme was chosen because of its proven reliability in capturing the storm centers (closed and open) in the EuroMediterranean region (Simmonds and Keay 2002; Pinto et al. 2005; Flocas et al. 2010; Syed et al. 2010; Nissen et al. 2010, 2013; Iordanidou et al. 2015; Almazroui et al. 2016). The MS scheme is used to identify and track storm centers which are having a life cycle of equal or more than 1 day and then performs statistical analysis. As a case study, we used the MS scheme to identify and track an exceptional Euro-Mediterranean winter storm Klaus-II at Z200 level (Fig. 1a). An extreme example "storm Klaus II", the continuation of the storm Klaus, which had caused huge damage to human life and property over western, central and southern Europe from 26th to 30th January, 
(a)

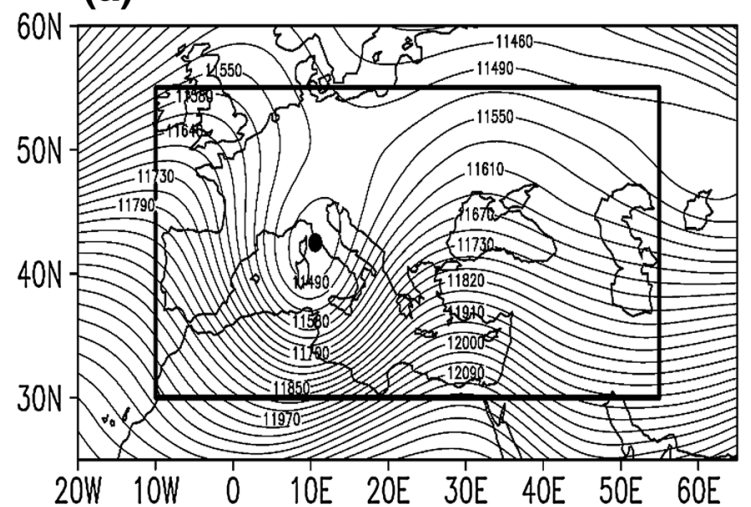

(b)

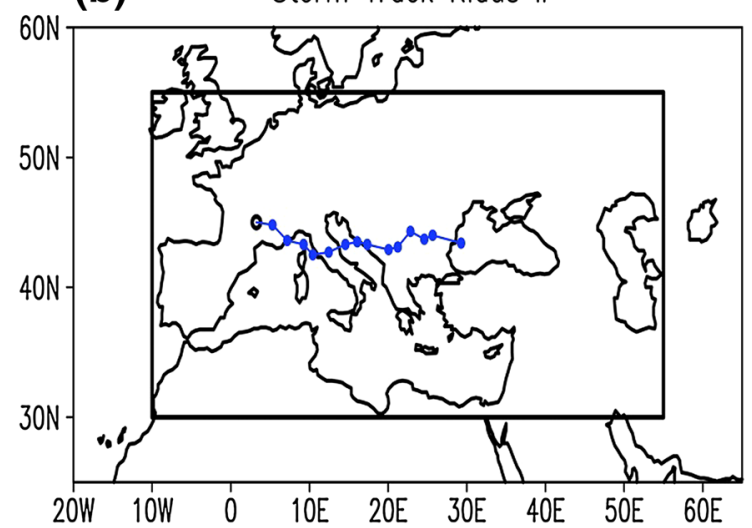

(c)

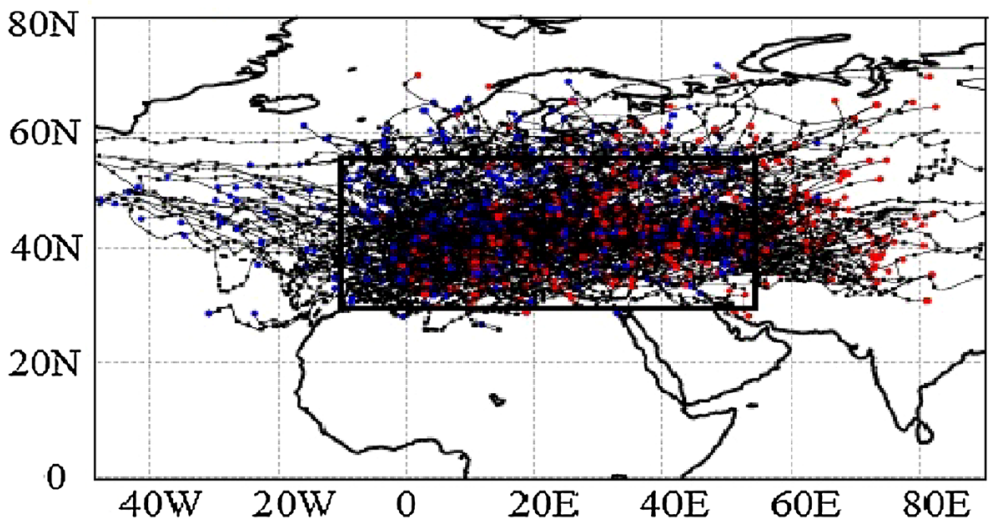

Fig. 1 a The Z200 storm center (marked by closed solid circles) identified by MS scheme at 1200 UTC on 27th Jan 2009. b The storm track Klaus II from 26th to 30th January, 2009. Open circles represent troughs while solid circles are strong closed systems. c Subset of

2009. Previously, the storms Klaus and Klaus II were identified and tracked using MSLP data in the MS scheme (Liberato et al. 2011). The storm Klaus II from 26th to 30th January, 2009 at Z200 level started over southern France as open cell and moved eastward over Mediterranean Sea up to western Black Sea (Fig. 1b). The identification and tracking of this historical event at Z200 shows that the adopted storm detection procedure may be used to identify storms. The long term storms analysis over Euro-Mediterranean was done using 6-hourly NCEP/ NCAR reanalysis datasets at $\mathrm{Z} 200$ with the grid resolution $2.5^{\circ} \times 2.5^{\circ}$ for the period 1950-2016. The spatial distribution of the cyclones gets somewhat shifted compared to those identified at the 500-hPa geopotential height and surface. With this fact in mind, Fig. 1c shows a subset of years (2000-2010) of NCEP storm tracks for boreal winter season lasting for more than 1 day and passing through the study domain $\left(10^{\circ} \mathrm{W}-55^{\circ} \mathrm{E} ; 30-55^{\circ} \mathrm{N}\right)$. Solid blue circles show the places of storm cyclogenesis and red circles represent the locations of storm cyclolysis. It is noted that there are three major source regions of storm tracks for the winter season storm tracks passing through the study domain during the period 2000-2010. Solid blue dots show cyclogenesis while Red dots represent cyclolysis of the storm track centers. The study domain $\left(10^{\circ} \mathrm{W}-55^{\circ} \mathrm{E} ; 30-55^{\circ} \mathrm{N}\right)$ is shown as rectangular box

Euro-Mediterranean region during the boreal winter season. The first major storm track source originates from the mid-latitude North Atlantic Ocean, especially from its central and eastern region. The second extends from northern and northwestern side of Europe to northwestern Russia. However, the majority of storm tracks originate from the Euro-Mediterranean region itself. Figure 1c clearly shows that the central and eastern Euro-Mediterranean is cyclogenesis as well as cyclolysis region.

\section{Results and Discussion}

The 67-year Euro-Mediterranean storm track frequency climatology (Fig. 2a) is prepared using NCEP reanalysis Z200 dataset in the MS scheme. The overall pattern shows that the largest storm track frequency values occur from the western Mediterranean Sea to Caspian Sea around the central and northern Mediterranean Sea region. The storm track maximum prevails in the study domain which covers the whole Mediterranean Sea, central/southern Europe and 
Fig. 2 a Climatology of Z200 storm track frequency [number of tracks per (deg.lat.) ${ }^{2}$ per winter season], b Standard deviation of the storm tracks frequency for the period 1950-2016

\section{(a) Mean}

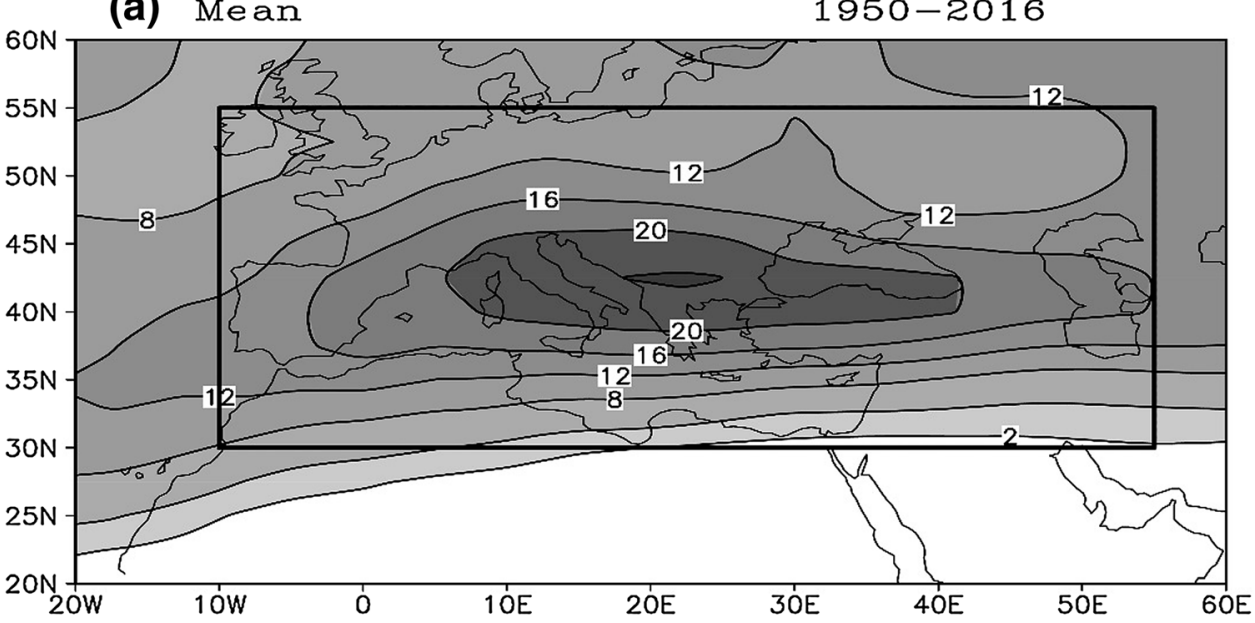

(b) Sandard deviation

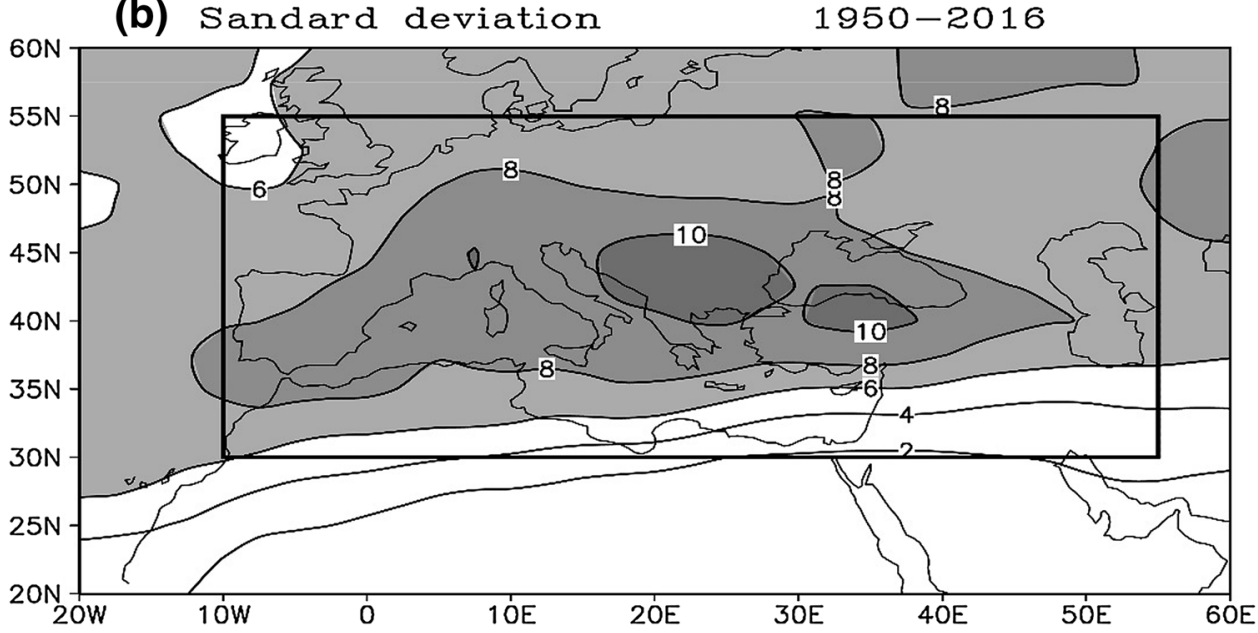

Middle East. The storm frequency maximum is located from the gulf of Genova to eastern Black Sea. Generally, the frequency of these large scale winter season storms affects the precipitation and sometimes causes extreme wind events in the Euro-Mediterranean region (Nissen et al. 2010, 2013).

The upper level cyclones and troughs mostly trigger the surface cyclone activity in their southeastern side (Holton 2004). The standard deviation of the mean storm track frequency field in winter is around 6 storms per year on average over the domain, with the maximum of 10 occurring over Greece (Fig. 2b). This shows that the mean interannual variability of the storm frequency in the study domain is very high and it is about $30 \%$ of the mean value. The interannual variability in storm frequency also influences interannual precipitation anomalies in the Euro-Mediterranean region. Topography and extension of the study area highly influence the storm track frequency and its seasonal distribution. The storm track frequency analysis show an average of 51 winter season storm tracks passes through the domain.
Further to establish a hypothesis about the mechanism by which the link between El Niño and Euro-Mediterranean storm frequency varies at multidecadal scales for the boreal winter season. The interannual variability reference time series of Euro-Mediterranean $\left(10^{\circ} \mathrm{W}-55^{\circ} \mathrm{E}\right.$; $30-55^{\circ} \mathrm{N}$ ) storm tracks is used for correlation purpose. The multidecadal relationship between the Euro-Mediterranean storm track frequency and ENSO is also investigated. The SST anomalies time series for winter season over the domain of $\left(170-120 \mathrm{~W}^{\circ} ; 5^{\circ} \mathrm{S}-5^{\circ} \mathrm{N}\right)$ is used as Niño 3.4 index, representing ENSO. The simultaneous correlation of the two time series is 0.1 for the whole 67 -year period. The sliding correlations are generated using a 21 -year window (Fig. 3a) for the investigation of decadal changes. It is found that the correlation was negative for the period 1960 to mid of 1985 and started to become positive after that. The correlation reached a maximum value close to 0.44 in the early 2002 and then maintained this value afterwards. It is interesting to note that just before mid-1985 when the correlation sign changed, the Pacific climate underwent a 
(a) Cor : Storm Freq vs Nino3.4 DJF 1950-2016

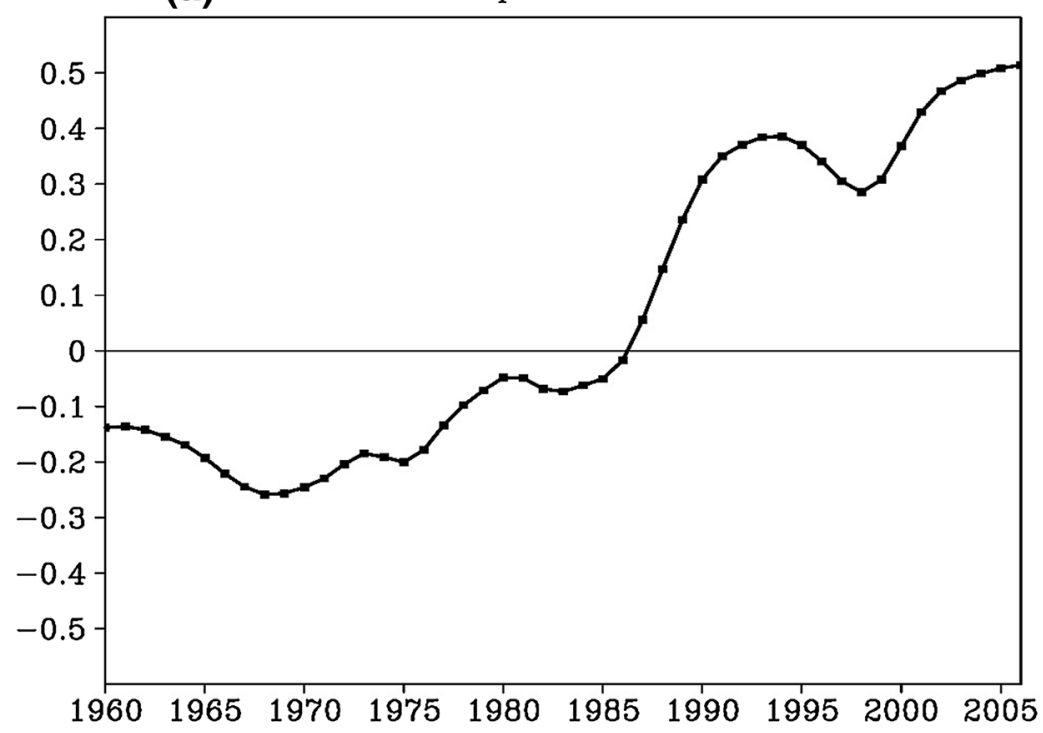

(b) Cor:(Storm Freq, SST DJF) 1950-1979

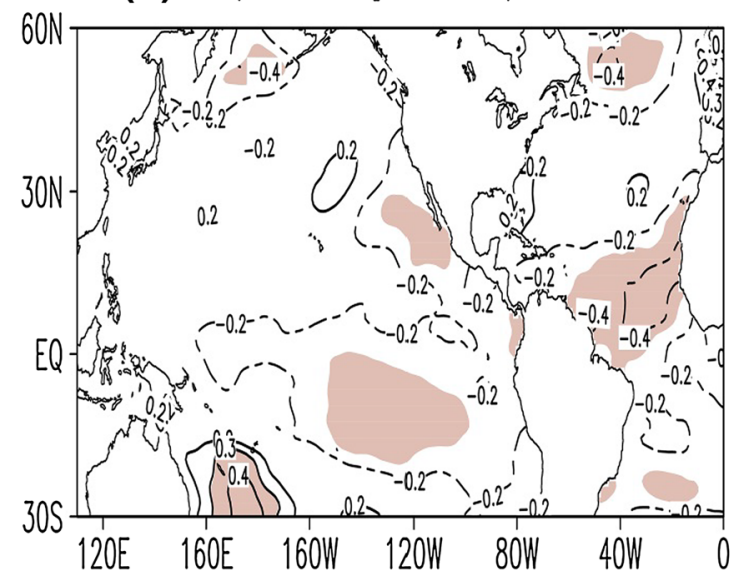

Fig. 3 a Twenty-one year sliding correlation between Euro-Mediterranean storm tracks frequency and Niño 3.4 index for the period 1950-2016. Correlation between the winter Euro-Mediterranean

climate shift (Graham 1994). The growth of ENSO was also different before and after the 1970s regime shift (Terray and Dominiak 2005).

To justify the aim of the hypothesis of this study, periods with or without statistically significant correlations with the Niño 3.4 index are analyzed separately. The running correlation is not significant in the early period (1950-1979) and it is significant but not high in the recent period (1987-2016). The departure between the two correlations during the two reference periods is approximately 0.68 and it is statistically significant at $95 \%$ confidence level. This shows that the relationship between winter season storm track frequency over Euro-Mediterranean region and Niño 3.4 index has changed significantly during the 67 year (c) Cor:(Storm Freq, SST DJF) 1987-2016

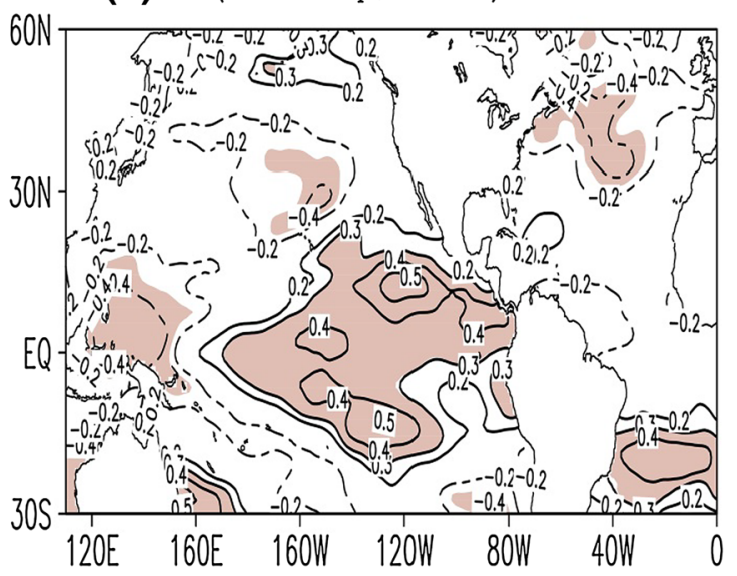

storm track frequency index with the SSTs for the two periods, i.e., b 1950-1979, c 1987-2016. Shaded regions are significant at 95\%

period from 1950 to 2016. The correlation coefficients sign between storm track frequency and tropical Pacific SST has been changed to better show the evaluation of the correlation in the phase with ENSO events (Fig. 3b, c).The shaded areas show statistical significant correlations at the $95 \%$ confidence level according to Student's $t$ test. It is observed that the Euro-Mediterranean storm frequency is slightly negatively correlated with Equatorial Pacific Ocean SST during the early period, whereas it is positively correlated with Equatorial Pacific Ocean SST and it is significant at 95\% confidence level during the recent period. It is found that the Equatorial Pacific SST influence on the EuroMediterranean Storm frequency has changed significantly for the last 67 years. Further, the sign of correlation over the 
North Atlantic Ocean is the same in both periods with a little change in values.

The strong western disturbances in the upper troposphere play the important role in the storm tracks. The ENSO associated variations in the upper tropospheric over North Atlantic and European sector can be seen in our analysis during the two periods. The mechanism for ENSO impact to European winter climate through troposphere and stratosphere has been discussed in the past studies (Ineson and Scaife 2009; Bell et al. 2009). Tropical climate variability on the decadal timescales of ENSO controls anomalous stationary eddies that propagate into the extratropics and influence the storm tracks (Shaw et al. 2016; Baggett and Lee 2015). The variations in polar vortex on interannual to decadal timescales can lead to storm track variability and trends (kidson et al. 2015). The interseasonal simultaneous correlation with Niño 3.4 shows that the Z200 anomalies are significantly changed over North Atlantic European sector and eastern Mediterranean region (Fig. 4a, b). The storm centers develop at the edges of the two anomalies (positive and negative). In the recent period, more ENSO related negative anomalies are prevailing over
Euro-Mediterranean region and it is northwards which may affect with more storm activity in the region (Fig. 4b). During the two periods, the Z200 correlation map shows a trough response over the North Atlantic with high pressure anomalies to the north and the south. This anomalous pattern shifts the jet stream position, and may strengthen the jet stream just to the south of the trough. Cyclones travel near the jet stream and will therefore follow this shift. In earlier period, the comparatively weak trough is located just to the north-west of the study domain, and cyclones affected by this anomaly may fail to enter the domain. On the other hand, in recent period, the comparatively stronger trough response is further south in the Atlantic Ocean and is located directly upstream of the study domain, so that cyclones influenced by the jet stream shift may enter the study domain. Another striking feature is the strengthening of the East Mediterranean trough during El Niño winters in recent period. A prominent change regarding the strength of the East Mediterranean trough during El Niño winters is noted. The large area with negative height anomalies over Eurasia might suggest deep trough development over the region and may result in (a) Cor (Nino3.4, Z200 DJF) 1950-1979

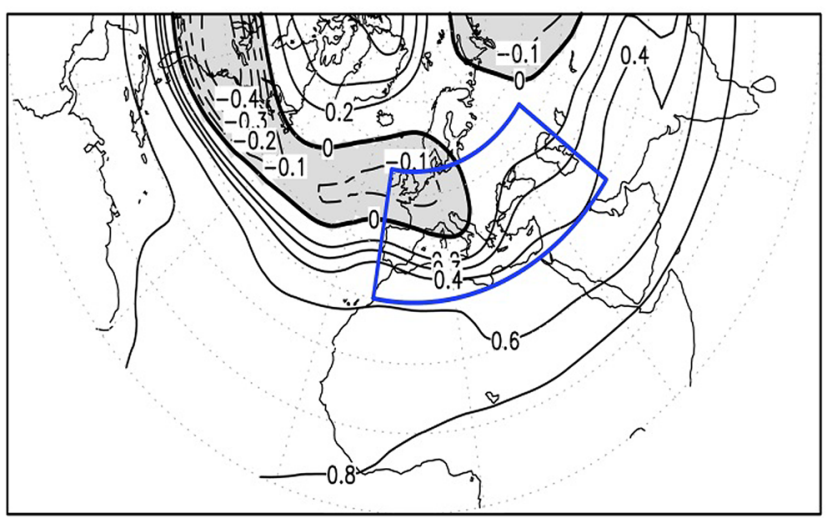

(c) Cor (Nino3.4, Z1000 DJF) 1950-1979

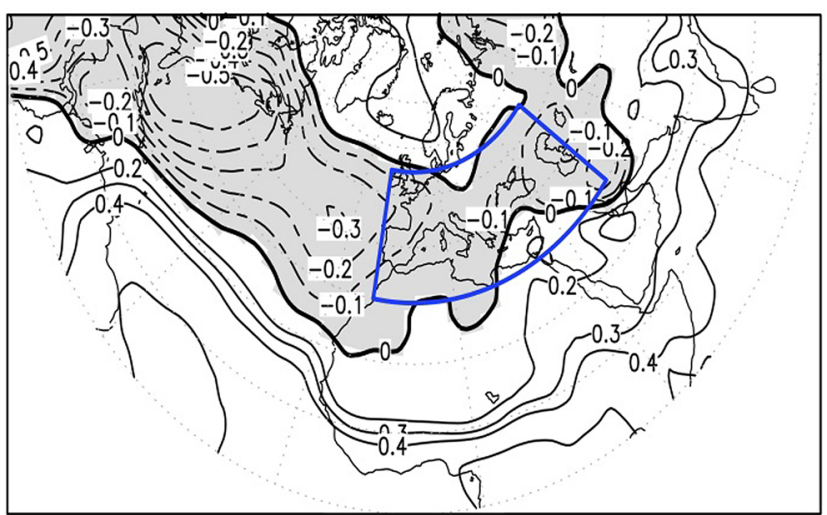

(b) Cor (Nino3.4, Z200 DJF) 1987-2016

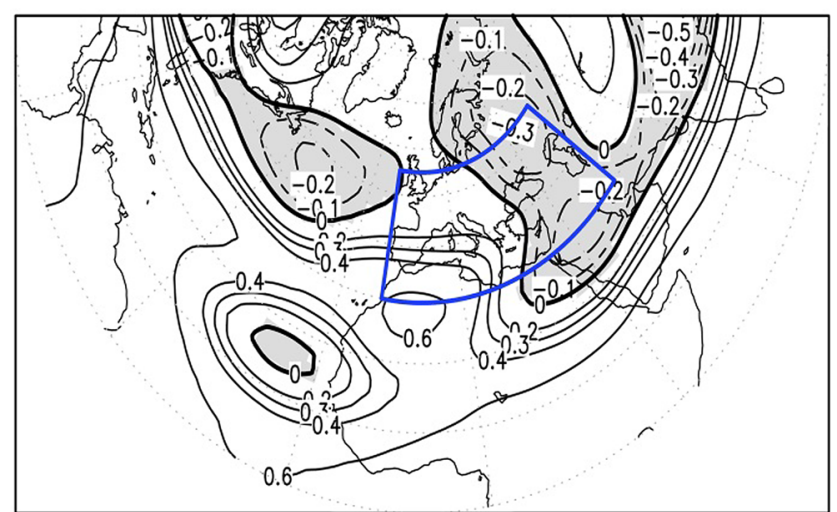

(d) Cor (Nino3.4, Z1000 DJF)

$1987-2016$

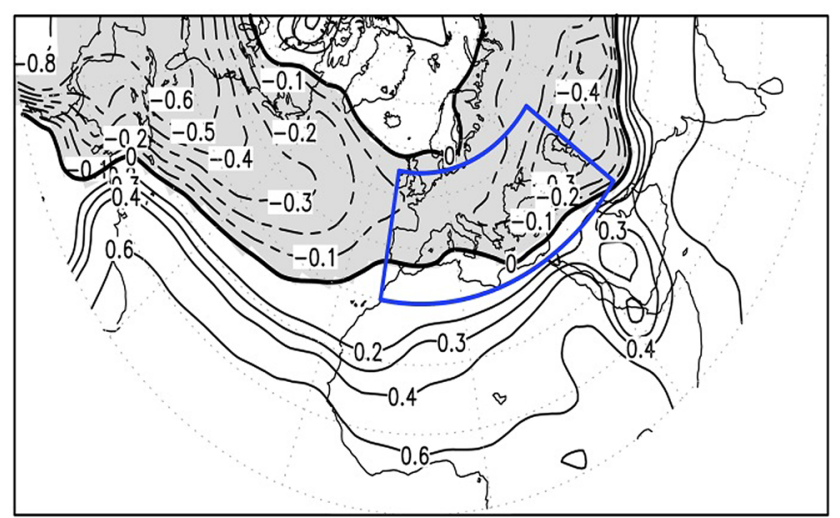

Fig. 4 Correlation of Niño 3.4 index with Z200 height for the two phases defined over the 30-year period of a 1950-1979, b 1987-2016, and correlation with Z1000, c 1950-1979, d 1987-2016 
stronger winter season storm activity affecting the eastern Euro-Mediterranean region. It is concluded from the upper tropospheric anomalies that the earlier El Niño/La Niña events slightly suppress/enhance the storm activity over the Euro-Mediterranean region. However, in the recent period, El Niño/La Niña events are strongly enhancing/suppressing the storm activity in the study domain. These upper tropospheric variations during two periods also propagate downward to the lower troposphere. It was established that upper tropospheric downstream development over northwest Europe causes surface cyclone development in the western and central Mediterranean (Prezerakos et al. 1999). Therefore, the upper tropospheric variations in height anomalies can be associated with lower troposphere storm activity variations which strongly influence the North Atlantic and Euro-Mediterranean region during the two periods (Fig. 4c, d). The weak negative anomalies with more spread over North Atlantic represents less storms from the upstream of the Euro-Mediterranean region and weak negative anomalies with less spread in central and eastern Euro-Mediterranean also show less storm activity (Fig. 4c).

The simultaneous correlations provide a more comprehensive picture of the changing relationship between storm frequency, storm intensity time series and Niño 3.4 index in the two reference periods which favors the hypothesis discussed above. It is found that the simultaneous correlation (Fig. 5) between Euro-Mediterranean storm track frequency and Niño 3.4 was -0.24 for earlier period (1950-1979). However, it is 0.44 for the recent 30-year period from 1987 to 2016 , which is statistically significant at $95 \%$ confidence level, representing that the ENSO teleconnection with storm frequency has changed significantly for the last 67-year period. The correlation between storm intensity (average Laplacian of geopotential value of the storm center which represents the storm intensity) and Niño 3.4 SST's has a positive value in both reference periods, but it is statistically significant only in the recent period. The multidecadal influence of the Equatorial

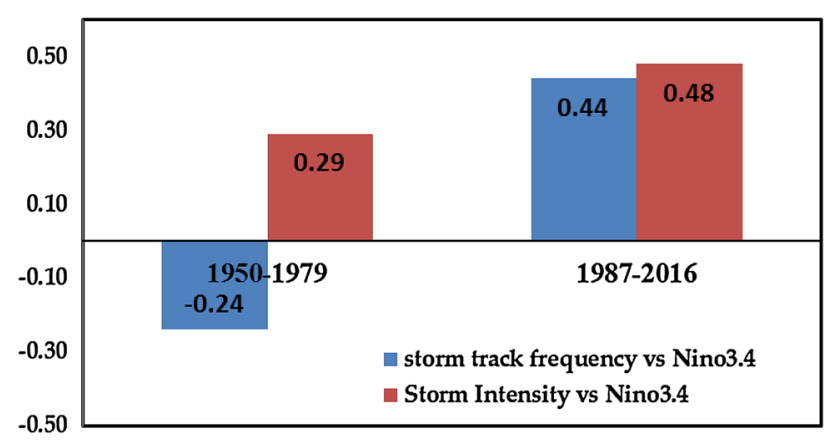

Fig. 5 Correlation coefficients (CC) between Euro-Mediterranean storm tracks frequency/intensity and Niño 3.4 index for two periods
Pacific Ocean SST over the Euro-Mediterranean storm frequency is nonstationary and it has changed significantly for the last 67 years.

The ENSO teleconnection is examined through composites of storm tracks frequency, and precipitation over Euro-Mediterranean region. The years of El Niño/La Niña are selected on the basis of the Niño 3.4 index value being equal or greater/less than $\pm 0.7 \mathrm{~K}$, respectively (Table 1 ). The ENSO composites are constructed by subtracting El Niño years from La Niña years. ENSO composite analysis focuses on the differences in the spatial distribution of the parameters over the Euro-Mediterranean region during the recent periods because of high correlation values. The ENSO composite shows increasing/decreasing storm tracks frequency during El-Niño/La-Niña (Fig. 6a) in the recent period. It shows that positive anomaly patterns are dominating in the study domain during El Niño events in the recent period. The link between ENSO and EuroMediterranean storm tracks frequency appears significant. The magnitude of the positive anomalies exceeds the typical range of interannual variability over the EuroMediterranean region during the recent period.

It has been shown that storms have a greater impact on the total precipitation in the DJF season compared to other seasons because the largest amount of precipitation occurs in the boreal winter (Hawcroft et al. 2012). The precipitation anomalies can be associated with extreme phases of ENSO due to its influence over Euro-Mediterranean storm frequency. The ENSO teleconnection impact on precipitation is examined through composites over the EuroMediterranean region in the recent period for which storm track frequency and Niño 3.4 SST's are significantly correlated. Precipitation composite analysis focuses on the differences of the spatial distribution in the EuroMediterranean region during the recent period. The ENSO rainfall composites (Fig. 6b) show mostly increasing/decreasing precipitation anomalies in the study domain during El Niño/La Niña events in the recent 30-year period. Winter season Euro-Mediterranean precipitation increases in a wide band across western and central parts during El Niño events and it extends eastward across Eurasian continent. The ENSO composite of precipitation shows that positive precipitation anomalies are prevailing over western, southern and southeastern Europe, Eastern

Table 1 El Niño/La Niña years extracted from COBE-SST dataset for DJF winter season

\begin{tabular}{|c|c|}
\hline Index & Years \\
\hline $\begin{array}{l}\text { El } \\
\text { Niño }\end{array}$ & $\begin{array}{l}\text { 1987, 1988, 1992, 1995, 1998, 2003, 2005, 2007, } 2010 \text {, } \\
\quad 2015,2016\end{array}$ \\
\hline $\begin{array}{l}\text { La } \\
\text { Niña }\end{array}$ & 1989, 1996, 1999, 2000, 2001, 2008, 2011, 2012 \\
\hline
\end{tabular}


(a) Storm Freq ENSO composite DJF (1987-2016)

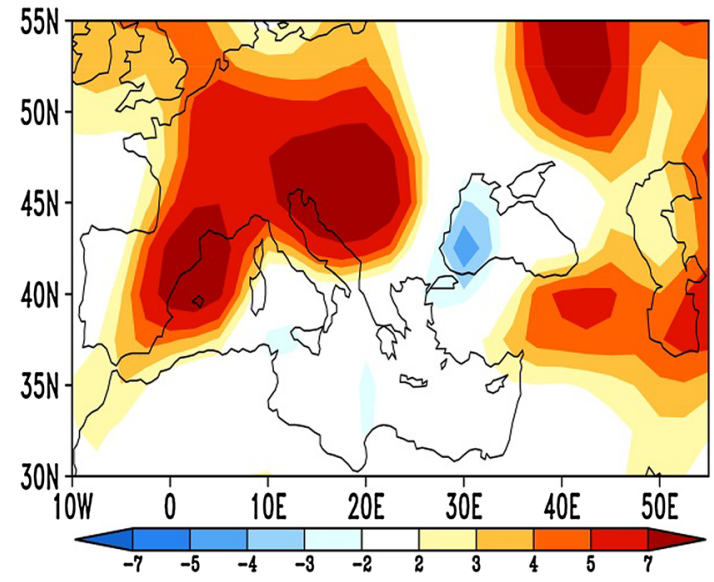

(b) PRCP ENSO composite DJF (1987-2016)

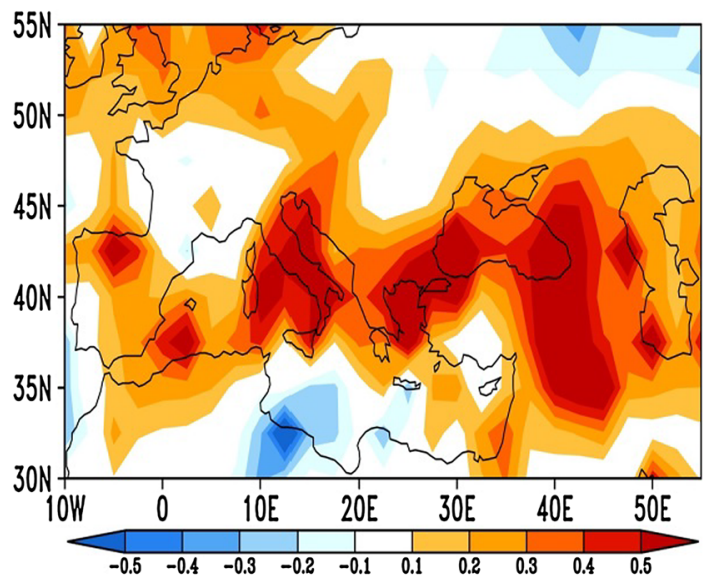

Fig. 6 a ENSO composite of storm track frequency (number of storm per degree latitude per winter season), b ENSO composite of precipitation anomalies (mm/day) for the period 1987-2016

Mediterranean region and Black Sea. From composite analysis, it can be observed that the response in EuroMediterranean storm frequency and precipitation to $\mathrm{El}$ Niño signal is large enough to be beneficial for seasonal predictability. The results from precipitation composite analysis are consistent with past studies (Mariotti et al. 2002; Ineson and Scaife 2009; Shaman and Tziperman 2011; Niranjan Kummar et al. 2016) in which it was shown that western Mediterranean, southern Europe and eastern Mediterranean regions receive more (less) than average rainfall during El Niño (La Niña) years.

Moreover, in future, the climate models such as SaudiKAU model (Almazroui et al. 2017) may be used to study the impact of other climate modes and circulation patterns on the Mediterranean storm tracks.

\section{Summary and Conclusion}

This study deals with the nonstationary relationship between winter season Euro-Mediterranean storm tracks frequency and El Niño during the second half of the twentieth century and start of the twenty-first century with its association to precipitation. The multidecadal variations in the strength of ENSO teleconnection to storm frequency have been calculated over Euro-Mediterranean for boreal winter season by means of 21-year running correlations. We found that a significant correlations phase shift occurred after the mid-1985, between Euro-Mediterranean storm track frequency and ENSO. The Euro-Mediterranean storm track frequency has a weak negative correlation with ENSO during the early period; however, it is positively correlated with a maximum correlation value of 0.44 for the more recent period. The decadal correlation departure between the two periods is about 0.68 and is a significant change in the relationship. This multidecadal variation in the relationship of Euro-Mediterranean storm activity and ENSO might be due to the alteration in central-eastern Pacific Ocean SST anomalies associated with ENSO. It is also found that ENSO provides a significant contribution to the interannual storm track frequency variability in the recent period. The ENSO-associated changes in the position of the jet stream play a vital role in the movement of the storm centers. A comparative southward shift in the jet stream position in the recent period is noted during the El Niño years. The storm centers traveling along the jet stream follow this shift and therefore enter in the study domain. A trough response appears in the central Atlantic Ocean just upstream of the study region. This trough and the negative Z200 anomalies in the eastern Mediterranean favor above normal storm activity in the study domain, and consequently increase the precipitation during El Niño events in the recent period. It was noted that ENSO has the nonstationary relationship with storm frequency at multidecadal scales and this relationship could be potentially used as a good predictor of rainfall over Euro-Mediterranean region during the boreal winter season, a finding that has important implications in seasonal predictability. The storm track frequency and precipitation maximums are modulated by ENSO over the Euro-Mediterranean region in the recent period.

Acknowledgements The authors would like to regard and acknowledge the Centre of Excellence for Climate Change Research (CECCR) and the Deanship of Graduate Studies (DGS), King Abdulaziz University for supporting this research work. The NCEP/ NCAR is acknowledged for reanalysis dataset through its website. Computation for the work described in this paper was performed using Aziz Supercomputer at King Abdulaziz University's High Performance Computing Center, Jeddah, Saudi Arabia. 
Open Access This article is distributed under the terms of the Creative Commons Attribution 4.0 International License (http://crea tivecommons.org/licenses/by/4.0/), which permits unrestricted use, distribution, and reproduction in any medium, provided you give appropriate credit to the original author(s) and the source, provide a link to the Creative Commons license, and indicate if changes were made.

\section{References}

Abid MA, Kang IS, Almazroui M, Kucharski F (2015) Contribution of synoptic transients to the potential predictability of PNA circulation anomalies: El Niño versus La Niña. J Clim 28(21):8347-8362. doi:10.1175/JCLI-D-14-00497.1

Abid MA, Kucharski F, Almazroui M, Kang IS (2016) Interannual rainfall variability and ECMWF-Sys4-based predictability over the Arabian Peninsula winter monsoon region. Q J R Meteorol Soc 142(694):233-242. doi:10.1002/qj.2648

Adler RF et al (2003) The version 2 global precipitation climatology project (GPCP) monthly precipitation analysis (1979-present). J Hydrometeorol 4:1147-1167

Alexander MA (1992) Midlatitude atmosphere-ocean interaction during El Niño. Part I: the North Pacific ocean. J Clim 5:944-958. doi:10.1175/1520-0442

Almazroui M, Kamil S, Ammar K, Keay K, Alamoudi AO (2016) Climatology of the $500-\mathrm{hPa}$ Mediterranean storms associated with Saudi Arabia wet season precipitation. Clim Dyn 47:3029-3042. doi:10.1007/s00382-016-3011-0

Almazroui M, Tayeb O, Mashat AS, Yousef A, Al-Turki YA, Abid MA, Bafail AO, Ehsan MA, Zahed A, Rahman MA, Mohorji AM, Kang IS, Noaman A, Omar M, Al-roqi AM, Ammar K, AlGhamdi AS, Hussein MA, Katib I, O'Brien E, Aljohani NR, Islam MN, Alsaedi A, Yang YM, Alkhalaf AK, Ismail M, Mashat A, Kucharski F, Assiri M, Ibrahim S, Tippett M, Rashid IU, Kamil S, Alahmadi A, Atif RM, Bajunaid MA, Hantoush AS (2017) Saudi-KAU coupled global climate model: description and performance. Earth Syst Environ. doi:10.1007/s41748-0170009-7

Baggett C, Lee S (2015) Arctic warming induced by tropically forced tapping of available potential energy and the role of the planetary-scale waves. J Atmos Sci 72:1562-1568

Bell CJ, Gray LJ, Charlton-Perez AJ, Scaife AA (2009) Stratospheric communication of ENSO teleconnections to European winter. J Clim 22:4083-4096

Bronnimann S (2007) Impact of El Niño-Southern Oscillation on European climate. Rev Geophys 45:RG3003. doi:10.1029/ 2006RG000199

Chang EKM, Fu Y (2002) Interdecadal variations in Northern Hemisphere winter storm track intensity. J Clim 15:642-658

Diaz HF, Hoerling MP, Eischeid JK (2001) ENSO variability, teleconnections and climate change. Int $\mathbf{J}$ Climatol 21:1845-1862

Ehsan MA, Kang IS, Almazroui M, Abid MA, Kucharski F (2013) A quantitative assessment of changes in seasonal potential predictability for the twentieth century. Clim Dyn 41:9-10. doi:10. 1007/s00382-013-1874-x

Ehsan et al (2017) Skill and predictability in multimodel ensemble forecasts for Northern Hemisphere regions with dominant winter precipitation. Clim Dyn. doi:10.1007/s00382-016-3267-4

Flocas HA et al (2010) On cyclonic tracks over the eastern Mediterranean. J Clim 23:5243-5257. doi:10.1175/2010JCLI3426.1

Graham NE (1994) Decadal scale variability in the 1970's and 1980's: observations and model results. Clim Dyn 10(3):135-162
Greatbach RJ, Lu J, KA Peterson (2004) Nonstationary impact of ENSO on Euro-Atlantic winter climate. Geophys Res Lett 31:L02208

Hawcroft M, Shaffrey L, Hodges K, Dacre H (2012) How much Northern Hemisphere precipitation is associated with extratropical cyclones. Geophys Res Lett 39(24):L24809. doi:10.1029/ 2012GL053866

Herceg Bulić I, Kucharski F (2012) Delayed ENSO impact on spring precipitation over North/Atlantic European region. Clim Dyn 38(11-12):2593-2612

Holton JR (2004) An introduction to dynamic meteorology. Elsevier Academic Press, Burlington

Hoskins BJ, Hodges KI (2002) New perspectives on the Northern Hemisphere winter storm tracks. J Atmos Sci 59:1041-1061. doi:10.1175/1520-0469

Ineson E, Scaife AA (2009) The role of the stratosphere in the European climate response to El Niño. Nat Geosci. doi:10.1038/ NGEO381

Iordanidou V, Koutroulis AG, Tsanis IK (2015) Mediterranean cyclone characteristics related to precipitation occurrence in Crete, Greece. Nat Hazards Earth Syst Sci 15:1807-1819. doi:10.5194/nhess-15-1807-2015

Ishii M, Shouji A, Sugimoto S, Matsumoto T (2005) Objective analysis of sea-surface temperature and marine meteorological variables for the 20th century using ICOADS and the Kobe collection. Int J Climatol 25:865-879

Kang IS, Rashid IU, Kucharski F, Almazroui M, Alkhalaf AA (2015) Multi-decadal changes in the relationship between ENSO and wet-season precipitation in the Arabian Peninsula. J Clim $28: 4743-4752$

Kidson J et al (2015) Stratospheric influence on tropospheric jet streams, storm tracks and surface weather. Nat Geosci 8:433-440

Knippertz P, Ulbrich U, Marques F, Corte-Real J (2003) Decadal changes in the link between El Niño and springtime North Atlantic Oscillation and European-North African rainfall. Int $\mathbf{J}$ Climatol 23:1293-1311. doi:10.1002/joc.944

Lau NC, Nath M (2001) Impact of ENSO on SST variability in the North Pacific and North Atlantic: seasonal dependence and role of extratropical air-sea coupling. J Clim 14:2846-2866

Liberato MLR, Pinto JG, Trigo IF, Trigo RM (2011) Klaus an exceptional winter storm over northern Iberia and southern France. Weather 66:330-334. doi:10.1002/wea.755

Lopez-Parages J, Rodriguez-Fonseca B (2012) Multidecadal modulation of El Niño influence on the Euro-Mediterranean rainfall. Geophys Res Lett 39:L02704

Mariotti A, Zeng N, Lau KM (2002) Euro-Mediterranean rainfall and ENSO - a seasonally varying relationship. Geophys Res Lett 29(12):59-1-59-4. doi:10.1029/2001GL014248

McPhaden MJ, Zebiak SE, Glantz MH (2006) ENSO as an integrating concept in Earth science. Science 314:1740-1745. doi:10.1126/ science. 1132588

Murray RJ, Simmonds I (1991a) A numerical scheme for tracking cyclone centres from digital data. Part I: development and operation of the scheme. Aust Met Mag 39:155-166

Murray RJ, Simmonds I (1991b) A numerical scheme for tracking cyclone centres from digital data. Part II: application to January and July general circulation model simulations. Aust Met Mag 39:167-180

Nakamura H, Sampe T, Tanimoto Y, Shimpo A (2004) Observed associations among storm tracks, jet streams and midlatitude oceanic fronts. Am Geophys Union 147:329-345

Niranjan Kummar K, Ouarda TBMJ, Sandeep S, Ajayamohan RS (2016) Wintertime precipitation variability over the Arabian Peninsula and its relationship with ENSO in the CAM4 simulations. Clim Dyn 47:2443-2454. doi:10.1007/s00382016-2973-2 
Nissen KM et al (2010) Cyclones causing wind storms in the Mediterranean: characteristics, trends and links to large-scale patterns. Nat Hazards Earth Syst Sci 10:1379-1391. doi:10.5194/ nhess-10-1379-2010

Nissen KM, Ulbrich U, Leckebusch GC (2013) Vb cyclones and associated rainfall extremes over Central Europe under present day and climate change conditions. Meteorol Z 22:649-660. doi:10.1127/0941-2948/2013/0514

Pinto JG, Spangehl T, Ulbrich U, Speth P (2005) Sensitivities of a cyclone detection and tracking algorithm: individual tracks and climatology. Meteorlog Z 14:823-838. doi:10.1127/0941-2948/ 2005/0068

Prezerakos NG, Flocas HA, Michaelides SC (1999) Upper-tropospheric downstream development leading to surface cyclogenesis in the central Mediterranean. Meteorol Appl 6:313-322

Ropelewski CF, Halpert MS (1987) Global and regional scale precipitation patterns associated with the El Nino/Southern Oscillation. Mon Weather Rev 115:1606-1626

Shaman J, Tziperman E (2011) An atmospheric teleconnection linking ENSO and Southwestern european precipitation. J Clim 24(1):124-139
Shaw TA et al (2016) Storm track processes and the opposing influences of climate change. Geoscience, Nat. doi:10.1038/ NGEO2783

Simmonds I, Keay K (2002) Surface fluxes of momentum and mechanical energy over the North Pacific and North Atlantic Oceans. Meteorol Atmos Phys 80:1-18

Straus DM, Shukla J (1997) Variations of midlatitude transient dynamics associated with ENSO. J Atmos Sci 54:777-790

Syed FS, Giorgi F, Palc JS, Keay K (2010) Regional climate model simulation of winter climate over Central-Southwest Asia, with emphasis on NAO and ENSO effects. Int J Climatol 30:220-235

Terray PS, Dominiak S (2005) Indian Ocean sea surface temperature and El Niño and Southern Oscillation: a new perspective. J Clim 18:1351-1368

Trigo IF, Davies TD, Bigg GR (1999) Objective climatology of cyclones in the Mediterranean region. J Clim 12:1685-1696

Van-Oldenborgh GJ, Burgers G (2005) Searching for decadal variations in ENSO precipitation teleconnections. Geophys Res Lett 32:L15701. doi:10.1029/2005GL023110

Wang C (2002) Atlantic climate variability and its associated atmospheric circulation cells. J Clim 15:1516-1536 